Academic Voices

A Multidisciplinary Journal

Volume 3, No. 1, 2013

ISSN 2091-1106

\title{
GREEN REVOLUTION IN PARSA: OPPORTUNITIES AND THREATS
}

\author{
Shiva Kant Dube \\ Department of Geography, TU, Thakur Ram Multiple Campus, Birganj, Nepal \\ Email: shivakant.dube@gmail.com
}

\begin{abstract}
This article has attempted to focus upon the concept, historical development, process and impact of green revolution at global context. It has also incorporated to emphasize the adverse impact resulted by green revolution. The widespread acceptance of High Yielding Variety Seeds (HYVs) and extensive adaptation of dwarfand semi-dwarf plants of short cropping period has intensified the production and productivity of agricultural crops. But, excessive and uncontrolled use of chemical fertilizers and pesticides, insufficient irrigation and small land holdings has diminished and impoverished the soil fertility leading to desertification. This study has also overviewed the scenario of agricultural production and productivity of crops in Parsa district of Nepal being a developing country after the diffusion and acceptance of green revolution. This study would attract the attentions of planners, policy makers, stakeholders and farmers towards entertaining the impact of green revolution and make them aware about the threat created by it now and in the coming future in Nepalese context.
\end{abstract}

\section{Key Words}

Revolution; High-yield varieties (HYV); Dwarf plants; Production \& Productivity; diffusion; desertification

\section{Introduction}

The term Green Revolution refers to the renovation of agricultural practices beginning in Mexico in the 1940s. Because of its success in producing more agricultural products there, Green Revolution technologies spread worldwide in the 1950 and 1960 , significantly increasing theamount of calories produced per acre of agriculture. Green Revolution refers to a series of research, development and technology transfer initiatives, occurring between the 1940s and the late 1960s, that increased agriculture production worldwide, particularly in the developing world, beginning most markedly in the late 1960 s 
(Hazell, 2009). The initiatives, led by Norman Borlaug, the "Father of the Green Revolution" credited with saving over a billion people from starvation, involved the development of highyielding varieties of cereal grains, expansion of irrigation infrastructure, modernization of management techniques, distribution of hybridized seeds, synthetic fertilizers, and pesticides to farmers.

The term "Green Revolution" was first coined in 1968 by former United States Agency for International Development (USAID) director William Gaud, who noted the spread of the new technologies: "These and other developments in the field of agriculture contain the makings of a new revolution. It is not a violent Red Revolution like that of the Soviets, nor is it a White Revolution like that of the Shah of Iran. I call it the Green Revolution" (Gaud, 1968).

\section{Definition}

\section{According to webster's dictionary}

"Green revolution may be defined as the simultaneous development of new varieties of food plants and improved agricultural techniques, resulting in greatly increased crop yields". Thus, green revolution is also known as "Biological Mechanical Revolution".

\section{History and development of the green revolution}

The beginnings of the Green Revolution are often attributed to Norman Borlaug, an American scientist interested in agriculture. In the 1940s, he began conducting research in Mexico and developed new disease resistance high-yield varieties (HYV) of wheat. By combining Borlaug's wheat varieties with new mechanized agricultural technologies, Mexico was able to produce more wheat than was needed by its own citizens, leading to its becoming an exporter of wheat by the 1960s. Prior to the use of these varieties, the country was importing almost half of its wheat supply.
Due to the success of the Green Revolution in Mexico, its technologies spread worldwide in the 1950 os and 1960s. The United States for instance, imported about half of its wheat in the 1940s but after using Green Revolution technologies, it became self-sufficient in the 1950 os and became an exporter by the 1960 .

In order to continue using Green Revolution technologies to produce more food for a growing population worldwide, the Rockefeller Foundation and the Ford Foundation, as well as many government agencies around the world funded increased research. In 1963 with the help of this funding, Mexico formed an international research institution called The International Maize and Wheat Improvement Center. The rapidly growing population trend of the world has been presented here under which needs more and more demand of food supply.

Table 1: World population growth trend (1950-2010)

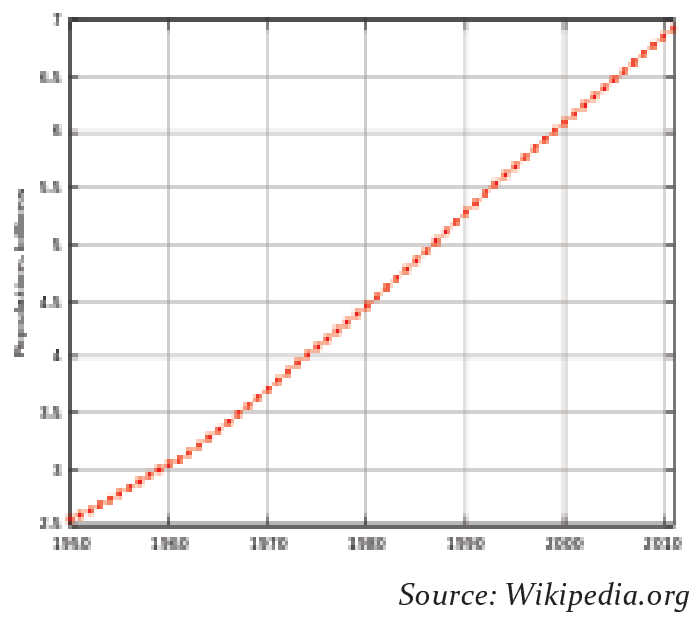

Table 1 shows the growing trend of world population from 1950-2010. According to World Population Data Sheet the population of the world was around 2.5 billion during 1950 which started to increase in skyrocketing speed after that and reached 3 billion in 1960, 4 billion in 1974, 5 billion on $11^{\text {th }}$ July, 1987 and 6 billion in 1999 (Bhende \& Kanitkar, 2006). 
The world population has crossed 7 billion marks on $31^{\text {st }}$ October, 2011 (UN, 2011) and approaching towards eight billion.

Countries all over the world in turn benefited from the Green Revolution work conducted by Borlaug and this research institution. India for example was on the brink of mass famine in the early 1960 os because of its rapidly growing population. Borlaug and the Ford Foundation then implemented research there and they developed a new variety of rice, IR8 that produced more grain per plant when grown with irrigation and fertilizers. Today, India is one of the world's leading rice producers and IR8 rice usage spread throughout Asia in the decades following the rice's development in India (Jain, 2010).

In 1961 India was on the brink of mass famine (News NG, 2013). Borlaug was invited to India by the adviser to the Indian minister of agriculture M. S. Swaminathan. Despite bureaucratic hurdles imposed by India's grain monopolies, the Ford Foundation and Indian government collaborated import wheat seed from CIMMYT. Similar achievements were made for wheat after Norman Borlaug (later awarded the Nobel Peace Prize for his work) crossed Japanese semi-dwarf varieties with Mexican wheat at what is now known as the International Center for Maize and Wheat Improvement (CIMMYT) in Mexico. Punjab was selected by the Indian government to be the first site to try the new crops because of its reliable water supply and a history of agricultural success. $\hat{\tilde{c}}$ India began its own Green Revolution development, and financing of agrochemicals (CGIAR, 2013).

India soon adopted IR8 - a semi-dwarf rice variety developed by the International Rice Research Institute (IRRI) that could produce more grains of rice per plant when grown with certain fertilizers and irrigation. In 1968, Indian agronomist S.K. De Datta published his findings that IR8 rice yielded about 5 tons per hectare with no fertilizer, and almost 10 tons per hectare under optimal conditions. This was 10 times the yield of traditional rice (Datta et al., 1968). IR8 was a success throughout Asia, and dubbed the "Miracle Rice". IR8 was also developed into Semi- dwarf IR36.

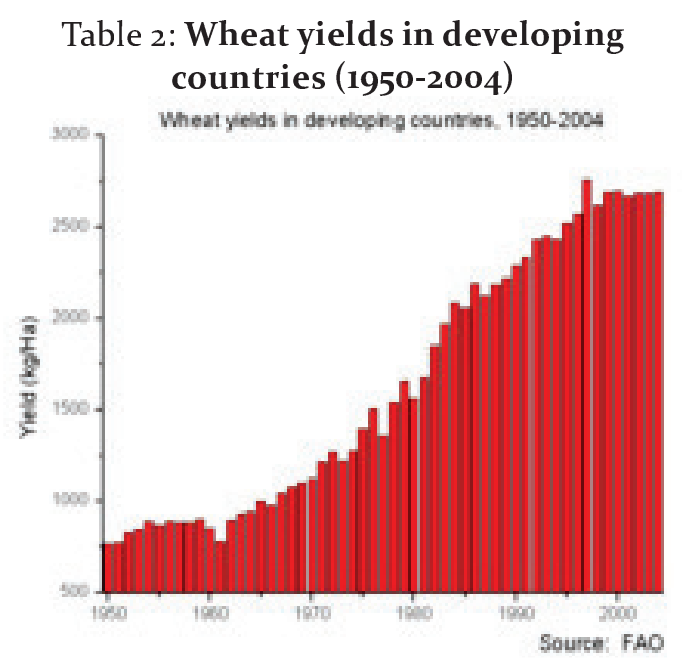

Table 2 illustrates wheat yields in developing countries, 1950 to 2004, kg/HA baseline 500. The steep rise in crop yields in the U.S. began in the 1940s. The percentage of growth was fastest in the early rapid growth stage. In developing countries maize yields are still rapidly rising (Fischer et al., 2007).

In the 1960s, rice yields in India were about two tons per hectare; by the mid-1990s, they had risen to six tons per hectare. In the 1970s, rice cost about $\$ 550$ a ton; in 2001, it cost under $\$ 200$ a ton (Barta, 2007). India became one of the world's most successful rice producers, and is now a major rice exporter, shipping nearly 4.5 million tons in 2006 .

\section{Plant technologies of the green revolution}

The crops developed during the Green Revolution were high yield varieties meaning they were domesticated plants bred specifically to respond to fertilizers and produce an increased amount of grain per acre planted. 
The terms often used with these plants that make them successful are harvest index, photosynthetic allocation, and insensitivity to day length. The harvest index refers to the above ground weight of the plant. During the Green Revolution, plants that had the largest seeds were selected to create the most production possible. After selectively breeding these plants, they evolved to all have the characteristic of larger seeds. These larger seeds then created more grain yield and a heavier above ground weight.

This larger above ground weight then led to an increased photosynthetic allocation. By maximizing the seed or food portion of the plant, it was able to use photosynthesis more efficiently because the energy produced during this process went directly to the food portion of the plant.

Finally, by selectively breeding plants that were not sensitive to day length, researchers like Borlaug were able to double a crop's production because the plants were not limited to certain areas of the globe based solely on the amount of light available to them.

\section{Impacts of the green revolution}

Since fertilizers are largely what made the Green Revolution possible, they forever changed agricultural practices because the high yield varieties developed during this time cannot grow successfully without the help of fertilizers.

Irrigation also played a large role in the Green Revolution and this forever changed the areas where various crops can be grown. For instance before the Green Revolution, agriculture was severely limited to areas with a significant amount of rainfall, but by using irrigation, water can be stored and sent to drier areas, putting more land intoagricultural production - thus increasing nationwide crop yields.

In addition, the development of high yield varieties meant that only a few species of say, rice started being grown. In India for example there were about 30,00o rice varieties prior to the Green Revolution, today there are around ten - all the most productive types. By having this increased crop homogeneity though the types were more prone to disease and pests because there were not enough varieties to fight them off. In order to protect these few varieties then, pesticide use grew as well (Hazell \& Ramaswamy, 1991).

There are varying opinions about the effect of the Green Revolution on wild biodiversity. One hypothesis speculates that by increasing production per unit of land area, agriculture will not need to expand into new, uncultivated areas to feed a growing human population (Davies, 2003). However, land degradation and soil nutrients depletion have forced farmers to clear up formerly forested areas in order to keep up with production (Shiva, 1991).

The Indian state of Punjab pioneered green revolutionamong theotherstatestransforming India into a food-surplus country. The state is witnessing serious consequences of intensive farming using chemicals and pesticide. A comprehensive study conducted by Post Graduate Institute of Medical Education and Research (PGIMER) has underlined the direct relationship between indiscriminate use of these chemicals and increased incidence of cancer in this region (Yadav, 2006). An increase in the number of cancer cases has been reported in several villages including Jhariwala, Koharwala, Puckka, Bhimawali, and Khara (Yadav, 2006).

Environmental activist Vandana Shiva has written extensively about the social, political and economic impacts of the Green Revolution in Punjab. She claims that the Green Revolution's reliance on heavy use of chemical inputs and monocultures has resulted in water scarcity, vulnerability to pests, and incidents of violent conflict and social marginalization (Shiva, 2011). 
Finally, the use of Green Revolution technologies exponentially increased the amount of food production worldwide. Places like India and China that once feared famine have not experienced it since implementing the use of IR8 rice and other food varieties.

\section{Impact of green revolution in production and productivity of parsa district}

Being an agrarian developing country, Nepal has also been influenced by the adaptation of green revolution as farmers have domesticated different hybrid seeds of agricultural crops which give more production and productivity to satisfy the food needs of the people. Though, Agriculture sector has contributed one third part in the gross domestic production of the nation but we still need to import around 100,000 quintals of food grains to satisfy food need of the people i.e.26,494,504 in our country (CBS, 2011). According to a recent article written by Beith Donford, Mission Director of USAID, Nepal more than 70 percent labor force still involves in agriculture where each one nepali citizen out of three are vulnerable to the food insecurity condition.

Parsa is one of the districts of Nepal which lies in the central development region having an area of 1353 sq. kms. It has 54732 hectares of land area in the district which is almost undulating flat very much suitable for agricultural crop production (Dube, 1999). The total population of this district is 601,017 having 6.29 average family size and with the growth rate 1.9 percent per annum (CBS, 2011). The total food need based on per person per annum food consumption i.e. $148.1 \mathrm{kgs}$ is 89010.6177 metric tons where as the total production in the fiscal year 2068/069 is 196146.38 metric tons (DADO Parsa, 2070 BS).

Table 3 demonstrates the total land area used for production of different types of crops in parsa district and the total production and productivity of the crops per annum in the last three consecutive fiscal years. It shows that there is gradual rise in the production and productivity of major crops like paddy, maize and wheat where as slight fluctuation is found to be seen in the production and productivity of oilseeds, pulses, potato and vegetables from fiscal year 2066/067 to 2068/069 BS. Sadanand Jaisi (Senior Soil Scientist-2070 BS) cited in his report that the nature of soil in parsa district is ranging from acidic to alkaline. The average $\mathrm{pH}$ value found among different sample test of soil in the district is 7.7 among which nearly 27 percent sample area out of the total soil sample taken needs treatment using calcium carbonate (Chun).

Table 3: Description of area, production and productivity of crops

\begin{tabular}{|c|c|c|c|c|c|c|c|c|c|}
\hline \multirow[b]{2}{*}{ Crops } & \multicolumn{3}{|c|}{ Fiscal Year 2066/067 BS } & \multicolumn{3}{|c|}{ Fiscal Year 2067/068 BS } & \multicolumn{3}{|c|}{ Fiscal Year 2068/069 BS } \\
\hline & $\begin{array}{c}\text { Area } \\
\text { (Hact.) }\end{array}$ & $\begin{array}{c}\text { Production } \\
\text { (M. T.) }\end{array}$ & $\begin{array}{l}\text { Productivity } \\
\text { (M.T./Hact.) }\end{array}$ & $\begin{array}{c}\text { Area } \\
\text { (Hact.) }\end{array}$ & $\begin{array}{c}\text { Production } \\
\text { (M. T. })\end{array}$ & $\begin{array}{l}\text { Productivity } \\
\text { (M.T./Hact.) }\end{array}$ & $\begin{array}{c}\text { Area } \\
\text { (Hact.) }\end{array}$ & $\begin{array}{c}\text { Production } \\
\text { (M. T.) }\end{array}$ & $\begin{array}{l}\text { Productivity } \\
\text { (M.T./Hact.) }\end{array}$ \\
\hline Paddy & 46690 & 159208 & $3 \cdot 4$ & 46700 & 164390 & $3 \cdot 52$ & 46700 & 193270 & 4.12 \\
\hline Maize & 5405 & 17457 & 3.22 & 5410 & 18935 & 3.5 & 5420 & 21257 & 3.92 \\
\hline Wheat & 23600 & 82600 & $3 \cdot 5$ & 23650 & 89680 & 3.8 & 23600 & 89680 & 3.8 \\
\hline Oilseed & 6265 & 6204.5 & 0.89 & 6970 & 6273 & 0.9 & 6977 & 6220.5 & 0.89 \\
\hline Pulses & 8205 & $10885 \cdot 5$ & 1.23 & 8251 & 12211.8 & 1.48 & 8260 & 11564 & 1.4 \\
\hline Potato & 1240 & 22525 & 26.5 & 1250 & 22375 & 17.9 & 1200 & 18000 & 15 \\
\hline Vegetable & ----- & ----- & ------ & 3050 & 53590 & $17 \cdot 57$ & 3200 & 57250 & 17.89 \\
\hline
\end{tabular}




\section{Criticism of the green revolution}

Along with the benefits gained from the Green Revolution, there have been several criticisms. The first is that the increased amount of food production has led to overpopulation worldwide.

The second major criticism is that places like Africa have not significantly benefited from the Green Revolution. The major problems surrounding the use of these technologies here though are a lack of infrastructure, governmental corruption, and insecurity in nations.

Despite these criticisms though, the Green Revolution has forever changed the way agriculture is conducted worldwide, benefiting the people of many nations in need of increased food production.

The Green Revolution has also been widely criticized for causing environmental damage. Excessive and inappropriate use of fertilizers and pesticides has polluted waterways, poisoned agricultural workers, killed beneficial insects and other wildlife. Irrigation practices have led to salt build-up and eventual abandonment of some of the best farming lands. Groundwater levels are retreating in areas where more water is being pumped for irrigation than can be replenished by the rains. And heavy dependence on a few major cereal varieties has led to loss of biodiversity on farms. Some of these outcomes were inevitable as millions of largely illiterate farmers began to use modern inputs for the first time, but inadequate extension and training, an absence of effective regulation of water quality, and input pricing and subsidy policies that made modern inputs too cheap and encouraged excessive use also created negative environmental impacts.

These problems are slowly being rectified without yield loss, and sometimes with yield increases, thanks to policy reforms and improved technologies and management practices, such as pest-resistant varieties, biological pest control, precision farming, and crop diversification. Often ignored, however, is the positive impact of higher yields in saving huge areas of forest and other environmentally fragile lands that would otherwise have been needed for farming? In Asia cereal production doubled between 1970 and 1975, yet the total land area cultivated with cereals increased by only 4 percent.

In Parsa district of Nepal, the total cultivated land area with cereal crops has not been increased so far where as the production and productivity gradually in the last three consecutive fiscal years have shown significant increase (DADO, 2070 BS). As cited by Jaisi (2070 BS) in the report of District Agriculture Development Office Parsa, there is found gradual decrease in the organic matters, amount of nitrogen, potassium, phosphorus, micro nutrients and $\mathrm{pH}$ value of the cultivated land area through soil sample tests.

\section{Conclusions}

Overall, the Green Revolution was a major achievement for many developing countries and gave them an unprecedented level of national food security. It represented the successful adaptation and transfer of the same scientific revolution in agriculture that the industrial countries had already appropriated for themselves. The Green Revolution also lifted large numbers of poor people out of poverty and helped many non poor people avoid the poverty and hunger they would have experienced had the Green Revolution not occurred. The largest benefits to the poor were mostly indirect, in the form of lower food prices, increased migration opportunities, and greater employment in the rural nonfarm economy. The direct benefits to the poor through their own on-farm adoption, greater agricultural employment, and empowerment have been more mixed and depend heavily on local socioeconomic conditions. In many cases inequalities between regions and communities that adopted Green Revolution technologies and those that did not also worsened. 
At the same time, the Green Revolution had many negative environmental impacts that have still to be adequately redressed. Agricultural research remains a potent force for good in the developing world and is the key to increasing yields further to meet the continuing growth of food needs in developing countries. This need is especially urgent in SubSaharan Africa, which has yet to experience an agricultural revolution of its own. But simply adding to the pile of food will not be enough. The indirect benefits for the poor are likely to be weaker in the future as globalization and trade make food prices less responsive to local production and as agriculture becomes less important to the livelihoods of the poor. Policymakers will need to target the poor more precisely to ensure that poor people receive greater direct benefits from new technologies. New technologies will also need to be more environmentally sustainable. By building on the strengths of the Green Revolution while seeking to avoid its weaknesses, scientists and policymakers can take significant steps toward achieving sustainable food security for the entire world's people.

In fact, the green revolution has changed the attitude of farmers towards production and productivity of the cereal crops from subsistence to commercialized activity. About one forth population of the world missed the benefits of green revolution and the overall situation is not satisfactory. Similar miracle is needed to be implemented for bypassed people of the world living in the harsh, dry areas. Thus, there is a need for "Grey to Green revolution".

However, the production and productivity trend in parsa district from the cultivated land area has shown substantial increase but the overall scenario is not satisfactory for longer period of time. The excess and unscientific use of chemical fertilizers, pesticides, insecticides, fungicides is very challenging to continue the production and productivity of cereal crops from the same cultivated land areas in the coming future due to diminishing return. Thus, planners, policy makers, stakeholders and farmers are advised to search for the better alternatives which can sustain the production and productivity from the same land area. Further research is also recommended in the agricultural field to satisfy the food needs of populace in Parsa district as well as in the country Nepal.

In nut shell, "Sustainable green revolution is an ecological and economic necessity in the country of small holdings and more farm families or agrarian developing country i.e. Nepal".

\section{Acknowledgements}

The autor is grateful to prof. Dr. A.S. Rayamane, Chairman of P.G. Dept. of Geography, Bangalore University, Bangalore, India for his guidance during preparation of the article as an expert. The writer is also thankful to prof. Dr. Abdul Quaiyum for his guidance and to Mr. Shyam Kishor Prasad Kurmi and other staffs of District Agriculture Development Office, Parsa for their kind support.

\section{References}

Barta, Patrick (28 July 2007). "Feeding Billions, A Grain at a Time". The Wall Street Journal. pp. Al.

Barshik Krishi Bikash Karyakram Tatha Tathyank Pustika (2068/069 BS). Birgunj: District Agriculture Development Office, Parsa.

Bhende, A., Kanitkar, T. (2006). Principles of Population Studies. Mumbai: Himalaya Publishing House, India.

Central Bureau of Statistics (2011). National Population and Housing Census National Report (2012). Kathmandu: Naitonal Planning Commission Secretariat.

Davies, Paul (June 2003). "An Historical Perspective from the Green Revolution to the Gene Revolution". Nutrition Reviews 61 (6): S124-34.

De Datta SK, Tauro AC, Balaoing SN (1 November 1968)."Effect of plant type and nitrogen level on 
growth characteristics and grain yield of indica rice in the tropics".Agron. J. 6o (6): 643-7.

Donford, B. (2013). "How to capacitate agriculture capacity in Nepal" an article (in nepali) published in the Kantipur daily on $14^{\text {th }}$ July, 2013.

Dube, S.K. (August 1999). District Introduction: Parsa. Kathmandu: The International Forum (Monthly) 15, 11, 40-41.

Fischer, R. A.; Byerlee, Eric; Edmeades, E. O. (2007) "Can Technology Deliver on the Yield Challenge to 2050". Expert Meeting on How to Feed the World (Food and Agriculture Organization of the United Nations).

Gaud, William S. (8 March 1968). "The Green Revolution: Accomplishments and Apprehensions". AgBioWorld. Retrieved 8 August 2011.

Hazell, P., and C. Ramasamy, The Green Revolution Reconsidered: The Impact of High-yielding Rice Varieties in South India (Baltimore, Md., U.S.A.: John Hopkins University Press for IFPRI, 1991).

Hazell, Peter B.R. (2009). "The Asian Green Revolution" IFPRI Discussion Paper (Intl Food Policy Res Inst).

Jain, H.K. (2010). The Green Revolution: History, Impact and Future (1st ed.). Houston, TX:
Studium Press. ISBN 1-933699-63-9. A brief history, for general readers.

Shiva, Vandana (March-April 1991). "The Green Revolution in the Punjab". The Ecologist 21 (2): 57-6o.

The Government of Punjab (2004). Human Development Report 2004, Punjab (Report). Retrieved 9 August 2011.Section: "The Green Revolution", pp. 17-20.

United Nations, World Population Prospects 2011, ST/ESA/SER, A/120, New York: 2011.

Yadav, S.F. (November 2006). "Green revolution's cancer train". Hardnews. Retrieved 28 December, 2013.

\section{websites}

"Green revolution in Punjab, by Vandana Shiva". Livingheritage.org. 15 October 1988. Retrieved 20 December, 2013.

"India Girds for Famine Linked With Flowering of Bamboo". News.nationalgeographic.com. Retrieved 13 December 2013.

"Newsroom: News Releases". CGIAR(Consultative Group on International Agricultural Research). Retrieved 13 December 2013. 